Review

\title{
Environmental Heavy Metal Contamination from Electronic Waste (E-Waste) Recycling Activities Worldwide: A Systematic Review from 2005 to 2017
}

\author{
M. G. Karel Houessionon ${ }^{1, *}$, Edgard-Marius D. Ouendo ${ }^{1}$, Catherine Bouland ${ }^{2} \mathbb{D}$, Sylvia A. Takyi ${ }^{3}$, \\ Nonvignon Marius Kedote ${ }^{1}\left(\mathbb{D}\right.$, Benjamin Fayomi ${ }^{4}$, Julius N. Fobil ${ }^{3} \mathbb{D}$ and Niladri Basu ${ }^{5}$ \\ 1 Regional Institute of Public Health Comlan Alfred Quenum, University of Abomey-Calavi, \\ Ouidah 384, Benin; eouendo@yahoo.fr (E.-M.D.O.); kedmar@yahoo.fr (N.M.K.) \\ 2 School of Public Health, Université Libre de Bruxelles, 1070 Brussels, Belgium; catherine.bouland@ulb.ac.be \\ 3 School of Public Health, University of Ghana, Accra LG 13, Ghana; phykles@gmail.com (S.A.T.); \\ jfobil@gmail.com (J.N.F.) \\ 4 Occupational Health and Environment Research Unit, University of Abomey-Calavi, Cotonou 06 555, Benin; \\ bfayomi2@yahoo.fr \\ 5 Department of Natural Resource Sciences, McGill University, Montreal, QC H9X 3V9, Canada; \\ niladri.basu@mcgill.ca \\ * Correspondence: karelhouessionon@yahoo.fr
}

\section{check for}

updates

Citation: Houessionon, M.G.K.; Ouendo, E.-M.D.; Bouland, C.; Takyi, S.A.; Kedote, N.M.; Fayomi, B.; Fobil, J.N.; Basu, N. Environmental Heavy Metal Contamination from Electronic Waste (E-Waste) Recycling Activities Worldwide: A Systematic Review from 2005 to 2017. Int. J. Environ. Res. Public Health 2021, 18, 3517. https:// doi.org/10.3390/ijerph18073517

Academic Editor: Paul Tchounwou

Received: 25 February 2021

Accepted: 24 March 2021

Published: 29 March 2021

Publisher's Note: MDPI stays neutral with regard to jurisdictional claims in published maps and institutional affiliations.

Copyright: (c) 2021 by the authors. Licensee MDPI, Basel, Switzerland. This article is an open access article distributed under the terms and conditions of the Creative Commons Attribution (CC BY) license (https:// creativecommons.org/licenses/by/ $4.0 /)$.

\begin{abstract}
The recycling of electronic waste (e-waste) contaminates ecosystems with metals, though a compilation of data from across sites worldwide is lacking, without which evidence-based comparisons and conclusions cannot be realized. As such, here, a systematic review of the literature was conducted to identify peer-reviewed studies concerning e-waste sites (published between 2005 and 2017) that reported on the concentration of heavy metals $(\mathrm{Cd}, \mathrm{Hg}, \mathrm{As}, \mathrm{Pb}$ and $\mathrm{Cr}$ ) in soil, water and sediment. From 3063 papers identified, 59 studies from 11 countries meeting predefined criteria were included. Reported metal concentrations were summarized, and a narrative synthesis was performed. This review summarized 8286 measurements of the aforementioned metals in soils (5836), water (1347) and sediment (1103). More than 70\% of the studies were conducted in Asia. In nearly all cases, the average metal concentrations in a particular medium from a given site were above guideline values; suggesting soils, water and sediment at, or near, e-waste recycling sites are contaminated. Across all media, concentrations of $\mathrm{Pb}$ were generally highest, followed by $\mathrm{Cr}, \mathrm{As}, \mathrm{Cd}$ and $\mathrm{Hg}$. The synthesized information demonstrates that e-waste sites worldwide are contaminated with metals, that geographic data gaps exist, that the quality of most studies can be improved and that action is needed to help reduce such levels to protect human health and the environment.
\end{abstract}

Keywords: e-waste; heavy metals; soil; water; sediment; environment

\section{Introduction}

The generation of electronic waste (e-waste) has rapidly emerged to become of growing concern worldwide [1,2]. For example, in 2019, the global community generated 53.6 million metric tons of e-waste, equivalent to $7.3 \mathrm{~kg}$ per person of e-waste per year, compared to $5.8 \mathrm{~kg}$ /person in 2014. By 2030, the amount of e-waste is expected to reach 74.7 million metric tons [3]. According to 2014 estimates, the largest e-waste producer was the United States (which produced 7.1 million tons), followed by China (which generated nearly 6.0 million tons). Regarding per capita generation, countries in Europe generated the most e-waste, averaging $15.6 \mathrm{~kg}$ of e-waste per person [4]. However, disparities have been observed between countries that produce e-waste and those that receive it. For example, there are estimates that China, India and some African countries receive up to $80 \%$ of global e-waste [5]. This exemplifies the disproportionate flow of e-waste from high-income 
countries to developing ones [6,7] even though we note that, in 2018, China introduced legislation to stop the import of e-waste into its territory [8].

Activities within the entire e-waste sector are notorious for contaminating ecosystems with a range of potentially toxic elements [9], as documented in several case studies from around the world [10-15]. This contamination of ecosystems is linked, among other things (such as processing and recycling), to the fact that e-waste continues to be dumped near rivers and deposited in illegal landfills $[6,16]$. Contaminants in e-waste include heavy metals known to be hazardous to environmental and human health [12,17-27]. It is important to note that the risk of contamination is more concerning in developing countries given that much of the work is practiced within the informal sector, unlike in, for example, Europe and North America where modern approaches and safety rules are instituted [3,28].

Despite the growing literature on ecosystem contamination at e-waste sites, there is a lack of a worldwide review on the subject matter from which we can synthesize global understanding, perform comparative studies (e.g., across sites or against guidelines), identify data gaps and ultimately draw evidence-based conclusions and make recommendations. Notably, a recent review by the WHO and the United States National Institute of Environmental Health Sciences_-U.S. NIEHS [29] — called out a need for better exposure measurements at e-waste sites, and particularly a synthesis of evidence on a worldwide basis given the tremendous variation that exists across locations. While some reviews on the subject matter have been conducted, they have targeted specific regions or countries [12,17,30-32], instead of trying to understand the worldwide situation. Thus, the objective of the current study was to perform a systematic review of the literature to identify peer-reviewed studies that reported on the concentration of heavy metals (Lead$\mathrm{Pb}$, Mercury- $\mathrm{Hg}$, Cadmium- $\mathrm{Cd}$, Arsenic - As and Chromium- $\mathrm{Cr}$ being amongst the most common and concerning in such sites [3]) in environmental media (soil, water and sediment) from e-waste sites worldwide. In doing so, this systematic review is intended to increase overall understanding of ecosystem contamination at e-waste recycling sites.

\section{Methods}

\subsection{Search Strategy}

A systematic review method was developed based on guidance from the United States Office of Health Assessment and Translation [33]. A literature search using MEDLINE and Web of Science (on 7 February 2018) was conducted using the following parameters: ((metals OR "heavy metal" OR mercury OR Hg OR Lead OR Pb OR chromium OR Cr OR cadmium OR Cd OR Arsenic OR As)) AND (((Sediment OR soil OR water)) AND ((((Ewaste) OR "electronic waste") OR WEEE) OR ("waste electric and electronic equipment"))).

\subsection{Study Selection Criteria}

The scientific papers were reviewed in a two-step process (Figure 1): first, the title and summary fields were queried for relevance, and second, the full texts were examined for articles that were considered potentially relevant. We focused our search to include articles that were original primary scientific studies (as opposed to reviews) that had abstracts available in English or French (which reflected the authors' backgrounds). We also focused on exposure assessment studies and did not include works that were principally focused on health outcomes or methods development. For studies to be included, we needed to access the full paper, and the work had to provide an estimate of the central tendency value and a measure of the variation from which an upper limit could be estimated. When a study was the subject of several articles, we chose the article containing the most complete dataset to serve as a representative piece. The scientific research studies included were carried out over the period of 2005-2017. 


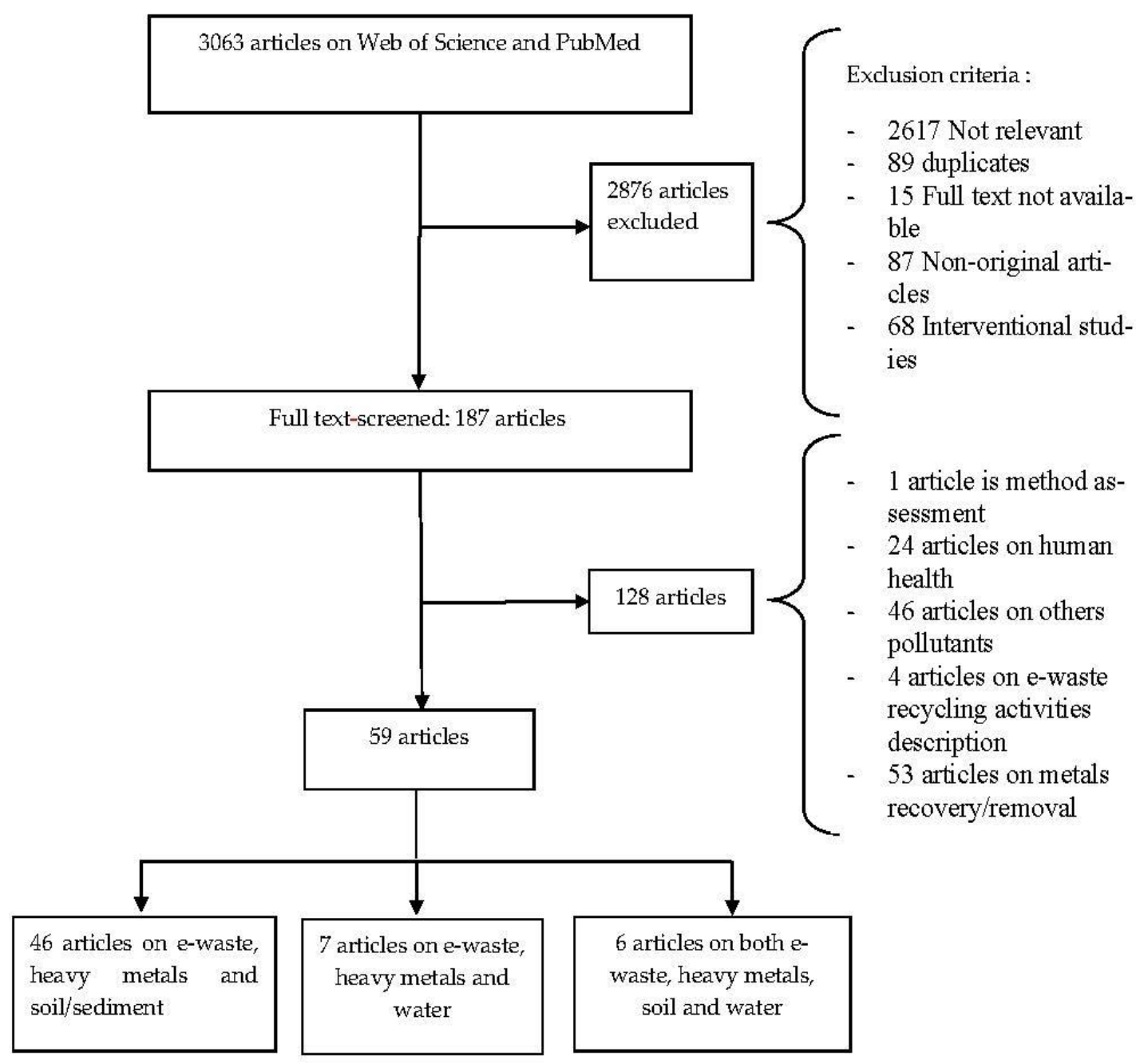

Figure 1. PRISMA flow diagram indicating the number of articles that were identified, screened and included in the current review. PRISMA = Preferred Reporting Items for Systematic Reviews and Meta-Analysis.

\subsection{Data Extraction and Analysis}

From each included paper, data were collected on the study design (sampling location, time, type of sample and sample size), measurement (units of measurement, technology for metal detection, detection limit, accuracy and precision), the type of heavy metal (As, $\mathrm{Hg}, \mathrm{Cr}, \mathrm{Cd}$ or $\mathrm{Pb}$ ) and the environmental media (soil, water and sediment), and the results were measured as both a central tendency value (geometric mean or median or mean) and a high-end value (95th or 90th or 75th percentile or maximum value).

The different units of measurement for metals from the studies included in this analysis were harmonized. All units were converted to $\mathrm{mg} / \mathrm{kg}$ for soil and sediment and $\mathrm{mg} / \mathrm{L}$ for water. This allowed us to easily make comparisons of heavy metal concentrations according to the studies, types of sampling area, countries and continents.

First, the extracted data were analyzed using Microsoft Excel 2013 software. Statistical analyses were done to synthesize the data according to the variables. Second, a narrative synthesis was done on all included studies, and key points on each of the items studied were reported.

\section{Results and Discussion}

\subsection{Overview}

The initial search of titles/abstracts resulted in 3063 published articles, of which 2856 were excluded, because they did not meet the predefined criteria (see Figure 1 PRISMA 
flowchart). Of the remaining 187 articles that were entirely read, 59 studies were included in this review, with reasons for excluding articles detailed in Figure 1.

The studies included in this analysis spanned 11 countries and were spread across all continents, except Europe. Of the 59 included studies, 71\% were conducted in China, $15.3 \%$ in Africa and $13.8 \%$ in the rest of the world. All the included studies were crosssectional. Only 15 out of the 59 studies had a reference site. Generally, the studies analyzed metals at e-waste recycling sites, around e-waste recycling sites, in specific dump sites, in free recycling sites and in residential areas. The metals were analyzed in various subcomponents of soil (top, middle, deep, farmland and forest), water (borehole, tap, well, spring, stream and drinking water) and sediment (dust and river). Of the five target metals, only $\mathrm{Pb}$ was common to all studies and measured in each (Table 1).

Table 1. Overview of included studies. As detailed in Figure 1, 59 peer-reviewed scientific articles met the criteria for inclusion in this systematic review, and here we provide key metadata for each of these studies. Additional details are in the Supplemental Materials, including a list of all the included articles.

\begin{tabular}{|c|c|c|c|c|c|}
\hline Regions & Countries & Metals Analyzed & Studies & Sample Type and Size & Sample Area \\
\hline Oceania & Australia & $\mathrm{As}, \mathrm{Cd}, \mathrm{Pb}, \mathrm{Cr}$ & 1 & Well water $(n=372)$ & $\begin{array}{ll}- & \text { Recycling site } \\
\text { - } & \text { Residential area }\end{array}$ \\
\hline \multirow{2}{*}{ Africa } & Ghana & $\mathrm{As}, \mathrm{Cd}, \mathrm{Pb}, \mathrm{Cr}, \mathrm{Hg}$ & 5 & $\begin{array}{ll}- & \text { Soil }(n=716) \\
- & \text { water (borehole, stream, } \\
& \text { spring, tap well) }(n=240)\end{array}$ & \multirow{2}{*}{$\begin{array}{ll}- & \text { Recycling site } \\
- & \text { Around recycling site } \\
- & \text { Abandoned recycling site } \\
- & \text { Dumping recycling site } \\
- & \text { Free recycling site }\end{array}$} \\
\hline & Nigeria & $\mathrm{As}, \mathrm{Cd}, \mathrm{Pb}, \mathrm{Cr}$ & 4 & $\begin{array}{ll}- & \text { Soil (top, middle, deep) } \\
& (n=633) \\
- & \text { water (tap, well) }(n=132)\end{array}$ & \\
\hline \multirow{7}{*}{ Asia } & China & $\begin{array}{l}\text { As, } \mathrm{Cd}, \mathrm{Pb}, \mathrm{Cr}, \mathrm{Hg} \\
\quad \mathrm{MeHg}, \mathrm{T}-\mathrm{Hg}\end{array}$ & 42 & $\begin{array}{ll}\text { - } & \text { Soil (top, middle, deep, } \\
\text { farmland, forest) }(n=4060) \\
\text { - } \quad \text { Water (well, drinking, pond, } \\
\text { fresh })(n=505) \\
\text { - } \quad \text { Sediment (dust, river }) \\
(n=1055)\end{array}$ & \multirow{7}{*}{$\begin{array}{ll}- & \text { Recycling site } \\
- & \text { Around recycling site } \\
- & \text { Abandoned recycling site } \\
- & \text { Dumping recycling site } \\
- & \text { Free recycling site } \\
- & \text { Residential area }\end{array}$} \\
\hline & India & As, Cd, $\mathrm{Pb}, \mathrm{Cr}, \mathrm{Hg}$ & 2 & $\begin{array}{ll}- & \text { Soil }(n=165) \\
- & \text { Well water }(n=50)\end{array}$ & \\
\hline & Japan & $\mathrm{Cd}, \mathrm{Pb}$ & 1 & Soil farmland soil $(n=40)$ & \\
\hline & Pakistan & $\mathrm{Pb}$ & 1 & Soil $(n=3)$ & \\
\hline & Philippines & $\mathrm{Pb}$ & 1 & Soil $(n=56)$ & \\
\hline & Thailand & $\mathrm{Pb}, \mathrm{Cr}$ & 2 & $\begin{array}{ll}- & \text { Soil }(n=75) \\
- & \text { Water }(n=48)\end{array}$ & \\
\hline & Vietnam & $\mathrm{Cd}, \mathrm{Pb}$ & 1 & $\begin{array}{ll}- & \text { Sediment (dust) }(n=48) \\
\text { - } & \text { Soil }(n=48)\end{array}$ & \\
\hline $\begin{array}{l}\text { South } \\
\text { America }\end{array}$ & Uruguay & $\mathrm{Pb}$ & 1 & Soil (40) & Residential area \\
\hline Total & - & - & $62 *$ & - & - \\
\hline
\end{tabular}

Regarding the instruments used to detect the heavy metals, about one-third (33.8\%) of the studies used inductively coupled plasma mass spectrometry, while the rest used atomic absorption spectroscopy $(22.1 \%)$, inductively coupled plasma atomic emission spectroscopy $(16.2 \%)$, inductively coupled plasma optical emission spectrometry $(14.7 \%)$ and atomic fluorescence spectrometry $(8.82 \%)$. 


\subsection{Soil Contamination}

The median values of the concentrations of heavy metals in the soil by country are summarized in Figure 2. In addition, Table 2 summarizes the middle and upper values of each heavy metal, each sample type and sample size. The Supplemental Materials provide details on sample sizes and middle and upper values of each heavy metal.

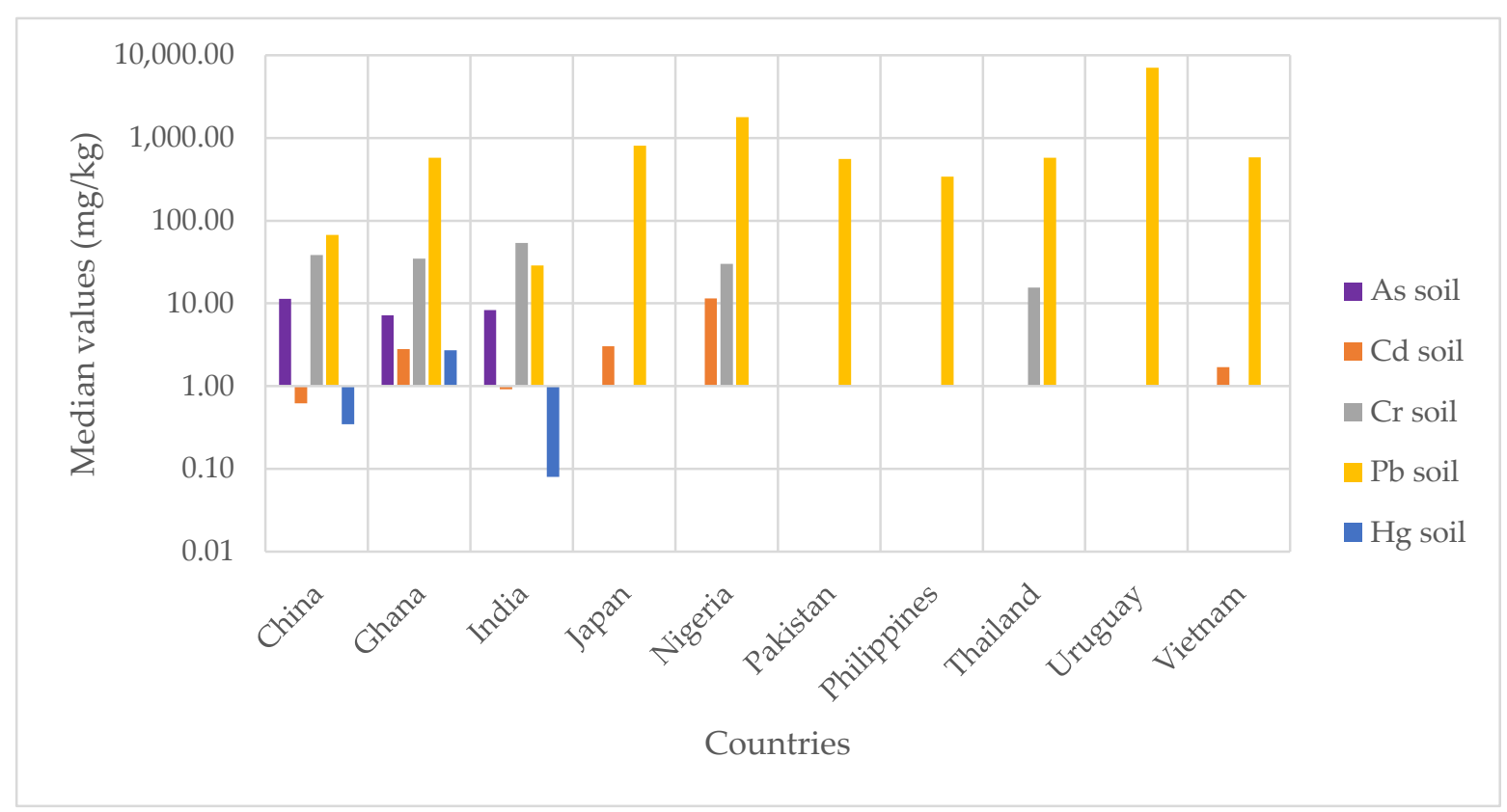

Figure 2. Median concentrations of heavy metals in soil by country.

Table 2. Summary of measured concentrations (central and upper values) of metals in e-waste sites for soil, water and sediment.

\begin{tabular}{cccccccccc}
\hline \multirow{2}{*}{ Metals } & \multicolumn{3}{c}{ Soil $(\mathrm{mg} / \mathrm{kg})$} & \multicolumn{3}{c}{ Water $(\mathrm{mg} / \mathrm{L})$} & \multicolumn{3}{c}{ Sediment (mg/kg) } \\
\cline { 2 - 10 } & $n$ & Middle & Upper & $\mathbf{N}$ & Middle & Upper & $N$ & Middle & Upper \\
\hline $\mathrm{As}$ & 595 & 9.55 & 18.95 & 241 & 0.0064 & 0.007 & 107 & 11.3 & 15.55 \\
\hline $\mathrm{Cd}$ & 1625 & 1.11 & 2.48 & 452 & 0.00049 & 0.00095 & 347 & 2.15 & 3.52 \\
\hline $\mathrm{Cr}$ & 1310 & 34.79 & 49.3 & 235 & 0.0022 & 0.0028 & 171 & 58 & 129.5 \\
\hline $\mathrm{Pb}$ & 1607 & 96.46 & 162.5 & 287 & 0.0063 & 0.01 & 371 & 233.5 & 287 \\
\hline $\mathrm{Hg}$ & 699 & 0.34 & 1.08 & 132 & 0.0005 & 0.0005 & 107 & 0.49 & 0.95 \\
\hline
\end{tabular}

\subsubsection{Arsenic in Soil}

In this group, 14 studies from three countries were identified, in which measurements of As were taken from 595 soil samples. The pooled central median concentration of As in soil was $9.55 \mathrm{mg} / \mathrm{kg}$ (see Figure 2) (interquartile range-IQR: $5.45-17.19 \mathrm{mg} / \mathrm{kg}$ ), with the upper bound median value being $18.95 \mathrm{mg} / \mathrm{kg}$ (Table 2 and Figure S1). The highest concentrations were recorded in China, followed by Ghana and India. It should be noted that in the sampling areas, the highest average concentrations of As were found in abandoned recycling sites [34], followed by recycling sites [35-37] (see Table 3). However, the highest concentration was identified by the study conducted by Li, Duan and Shi [35]. This may be explained by the fact that there have been many more studies on recycling sites than on abandoned recycling sites, which have only been the subject of one study [34]. 
Table 3. Summary of the average central value concentration of certain metals according to specific sample areas in e-waste sites.

\begin{tabular}{|c|c|c|c|c|c|}
\hline Metals & $\begin{array}{c}\text { Abandoned } \\
\text { Recycling Site }\end{array}$ & Around Recycling Site & Free Recycling Site & Recycling Site & Residential Area \\
\hline \multicolumn{6}{|c|}{ Soil (mg/kg) } \\
\hline As & 36.60 & 7.73 & 9.89 & 34.72 & 0.28 \\
\hline $\mathrm{Cd}$ & 21.28 & 0.91 & 0.27 & 48.36 & 0.04 \\
\hline $\mathrm{Cr}$ & 388.96 & 34.05 & 23.34 & 65.46 & 16.35 \\
\hline $\mathrm{Pb}$ & 2221.70 & 97.86 & 32.75 & 729.95 & 3565.71 \\
\hline $\mathrm{Hg}$ & 568.03 & 0.25 & 50.05 & 222.71 & \\
\hline \multicolumn{6}{|c|}{ Water (mg/L) } \\
\hline As & \multirow{5}{*}{ No data } & 0.01 & 0.00 & 0.31 & 0.01 \\
\hline $\mathrm{Cd}$ & & 0.77 & 0.00 & 0.38 & 0.00 \\
\hline $\mathrm{Cr}$ & & 4.88 & 0.00 & 0.30 & 0.01 \\
\hline $\mathrm{Pb}$ & & 188.19 & 0.00 & 0.43 & 0.01 \\
\hline $\mathrm{Hg}$ & & 0.00 & 0.00 & 0.06 & \\
\hline \multicolumn{6}{|c|}{ Sediment (mg/kg) } \\
\hline As & \multirow{5}{*}{ No data } & 0.29 & 6.36 & 11.39 & \multirow{5}{*}{ No data } \\
\hline $\mathrm{Cd}$ & & 3.82 & 0.98 & 3.82 & \\
\hline $\mathrm{Cr}$ & & 73.61 & 43.73 & 136.19 & \\
\hline $\mathrm{Pb}$ & & 3894.50 & 82.62 & 9699.13 & \\
\hline $\mathrm{Hg}$ & & 0.00 & 0.16 & 0.81 & \\
\hline
\end{tabular}

Comparing the values of each study with the United States Environmental Protection Agency (USEPA) guidelines [38], it can be seen that only the value recorded in the Wang et al. [39] study, conducted around a recycling site, is below the standard. All other values from other studies are well above the recommendation (see Figure S1). In addition, even studies that have included free recycling sites report values above the standards $[36,40]$, which shows the extent of soil pollution by As from e-waste.

\subsubsection{Cadmium in Soil}

In this group, 36 studies from six countries were identified. Combined, these studies analyzed 1625 soil samples in total. The pooled central median concentration of $\mathrm{Cd}$ in soil was $1.11 \mathrm{mg} / \mathrm{kg}$ (Figure 2) (IQR: $0.18-4.81 \mathrm{mg} / \mathrm{kg}$ ), with the upper bound median value being $2.48 \mathrm{mg} / \mathrm{kg}$ (Table 2 and Figure S2). The highest concentrations were recorded in China [41], followed by Ghana [40], India [42], Nigeria [43], Japan [44] and Vietnam [45] (see Figure S2). In fact, almost all studies on Cd and soil have been conducted in China. In the sampling areas, the highest concentrations of $\mathrm{Cd}$ in soil were recorded in recycling sites [41,43,46-48], followed by abandoned recycling sites [34,46] (see Table 3).

As presented in Figure S2, comparison of the upper values in the literature with the USEPA guidelines shows that, in China, several values are above the recommended limit [34,41,46-51]. In addition, several other studies have reported above-standard values in Ghana [40,52,53], India [42] and Nigeria [43].

\subsubsection{Chromium in Soil}

In this group, 32 studies from five countries were identified. Combined, these studies analyzed 1310 soil samples in total. The pooled central median concentration of $\mathrm{Cr}$ in soil was $34.79 \mathrm{mg} / \mathrm{kg}$ (see Figure 2) (IQR: 18.97-69.36 mg/kg), with the upper bound median value being $49.3 \mathrm{mg} / \mathrm{kg}$ (Table 2 and Figure S3). The highest concentrations were recorded in Ghana [53], followed by China [35], India [42], Nigeria [43] and Thailand [54], in that 
order. In fact, almost all the studies on $\mathrm{Cr}$ and soil have been conducted in China and Ghana (see Figure S3). The high $\mathrm{Cr}$ concentrations according to the sampling areas were recorded in abandoned recycling sites [34,46], followed by recycling sites $[25,35,48,53,55-57]$ and around recycling sites $[22,34,36,55,58,59]$ (see Table 3).

According to Figure S3, the comparison between $\mathrm{Cr}$ values in soil and the USEPA guidelines shows that only the study by Quan et al. [60] reported values below the standard. All other studies reported values well above the recommended limit (Figure S3). It should be noted that even studies that have included non-recycling sites report values above the standard $[36,40,58,60,61]$. This further shows the extent of soil pollution by $\mathrm{Cr}$ from e-waste.

\subsubsection{Lead in Soil}

In this group, 42 studies from 10 countries were identified. Combined, these studies analyzed a total of 1607 soil samples. The combined central median concentration of $\mathrm{Pb}$ in soil was $96.46 \mathrm{mg} / \mathrm{kg}$ (see Figure 2) (IQR: $46.88-466.5 \mathrm{mg} / \mathrm{kg}$ ) with the upper bound median value being $162.5 \mathrm{mg} / \mathrm{kg}$ (Table 2 and Figure S4). The highest concentrations were recorded in Uruguay [62], followed by Ghana [52], China [50], Thailand [18], Nigeria [43], India [42], Japan [44], Vietnam [45], the Philippines [23] and Pakistan [63], in decreasing order (see Figure S4). It should be noted that about $2 / 3$ of studies on soil contamination by $\mathrm{Pb}$ were conducted in China. Table 3 shows that the high concentrations were recorded in residential areas, even though they were near recycling sites [62], followed by abandoned recycling sites $[34,46,64]$ and recycling sites $[10,18,36,40,43,44,65,66]$.

By comparing the soil $\mathrm{Pb}$ upper values reported in the literature and USEPA guidelines, many of them are above the accepted limit. These non-standard values have been found in Uruguay [62], Ghana [10,40,52,53], China [34,36,46,50,64,66], India [42], Japan [44], Nigeria [43], Pakistan [63], the Philippines [23], Thailand [18] and Vietnam [45].

\subsubsection{Mercury in Soil}

In this group, 42 studies from 10 countries were identified. Combined, these studies analyzed a total of 699 soil samples. The pooled central median concentration of $\mathrm{Hg}$ in soil was $0.34 \mathrm{mg} / \mathrm{kg}$ (see Figure 2) (IQR: 0.09-2.47 mg/kg), with the upper bound median value being $1.08 \mathrm{mg} / \mathrm{kg}$ (Table 2 and Figure S5). It should be noted that the highest concentrations were recorded in China [60], followed by Ghana [52] and India [42]. Almost all studies on soil contamination by $\mathrm{Hg}$ have been conducted in China (see Figure S5). As presented in Table 3 , the high concentrations of $\mathrm{Hg}$ in soil according to the sampling areas were recorded in abandoned recycling sites [34,67], followed by recycling sites [42,53,60,67].

The comparison between the upper values of $\mathrm{Hg}$ in soil reported in the literature and the USEPA guidelines shows that several concentrations are above the guidelines (Figure S5). These non-standard concentrations have been recorded in China $[34,50,60,67]$, Ghana [52,53] and India [42]. It should be noted that one study found values above the standard in a free recycling site [67]. This shows the extent of soil pollution by $\mathrm{Hg}$ contained in e-waste.

\subsubsection{Summary of Studies Concerning Metals in Soil}

By synthesizing the information on all heavy metals in soil, we note in this systematic review a predominance of studies conducted in Asia, especially in China, on the contamination of soils by heavy metals from e-waste recycling. The imbalance of the scientific data on the topic does not allow for a global perspective, such that a more or less universal decision may be made or conclusion drawn. It is therefore important to conduct studies in other developing regions so that the analysis is truly global.

In addition, studies on soil contamination by heavy metals are more numerous than studies on other aspects of environmental contamination (water and sediment). This situation could be explained, first, by the position of the soil in relation to recycling activities and the ease with which a scientist can determine the heavy metals in the soil and attribute the concentrations directly to e-waste. Indeed, e-waste is recycled on soil and 
this direct contact obviously explains the concentrations detected in the soil $[35,68]$. On the other hand, contamination of water and sediment can take place through infiltration or resuspension of the particles, with many confounding factors to be accounted for by the scientist [69]. In fact, at or near most e-waste recycling sites, there are usually many other human activities (e.g., vehicular traffic, food preparation, biomass burning) that can contaminate ecosystems. Secondly, soil sampling can be done at the surface or at depth with less expensive equipment and simple techniques, while the sampling of water requires specific techniques and equipment, depending on whether it is surface water or groundwater [69].

\subsection{Water Contamination}

The median values of the concentrations of heavy metals (As, $\mathrm{Cd}, \mathrm{Cr}, \mathrm{Pb}$ and $\mathrm{Hg}$ ) in water by country are summarized in Figure 3. In addition, Table 2 summarizes the middle and upper values of each heavy metal, each sample type and sample size. The Supplemental Materials provide details on sample sizes and middle and upper values of each heavy metal.

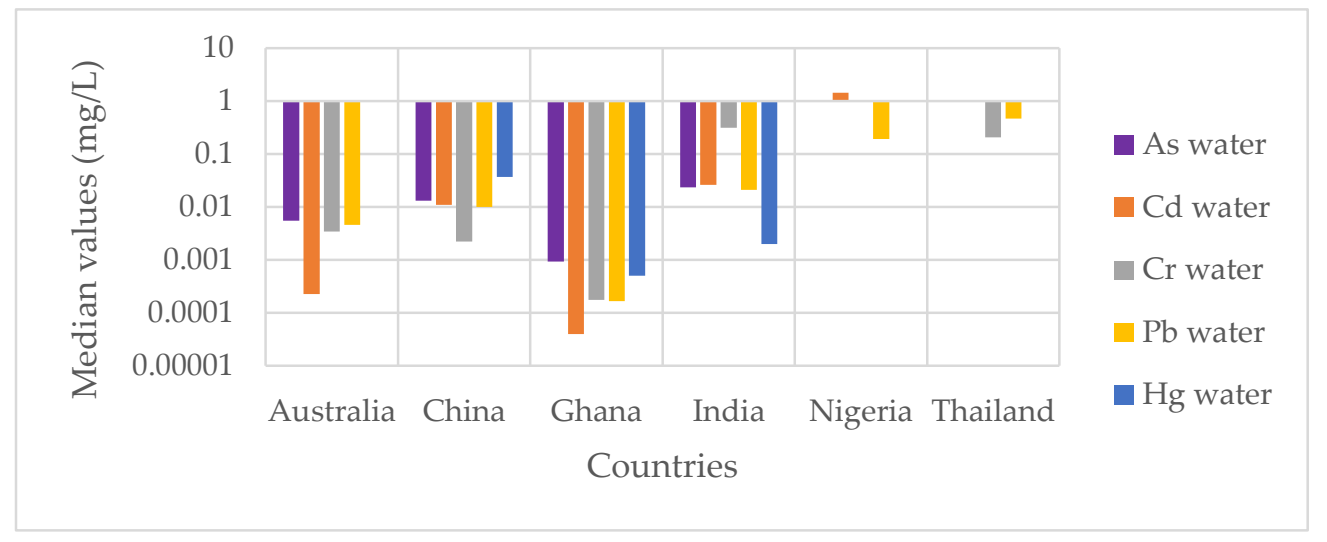

Figure 3. Median concentrations of heavy metals in water by country.

\subsubsection{Arsenic in Water}

In this group, six studies from five countries were identified. Combined, these studies analyzed 241 water samples in total. The pooled central median concentration of arsenic in water was $0.0064 \mathrm{mg} / \mathrm{L}$ (see Figure 3) (IQR: 0.001-0.016 mg/L), with the upper bound median being $0.007 \mathrm{mg} / \mathrm{L}$ (Table 2 and Figure S6). The highest concentrations were recorded in China [70], followed by India [56], Australia [71] and Ghana [72] (see Figure S6). Analysis of the values reported in the literature by sampling area shows that the highest concentrations of As in water were recorded in recycling sites [56,70,71] (see Table 3).

Comparing the upper values of As in water with WHO guidelines [73], it can be seen that some concentrations are above the recommended limit (see Figure S6). These limit exceedances were observed in China [70] and India [56].

\subsubsection{Cadmium in Water}

In this group, 10 studies from five countries were identified. Combined, these studies analyzed 452 water samples. The combined central median concentration of $\mathrm{Cd}$ in water was $0.00049 \mathrm{mg} / \mathrm{L}$ (see Figure 3) (IQR: 0.00004-0.07 mg/L), with the upper bound median value being $0.00095 \mathrm{mg} / \mathrm{L}$ (Table 2 and Figure S7). The highest concentrations were recorded in China [46], followed by Nigeria [74], India [56], Australia [71] and Ghana [72]. As Table 3 presents, analysis of the upper values reported in the literature by sampling area shows that water from around recycling sites $[46,74,75]$ is more contaminated by $\mathrm{Cd}$, followed by recycling sites $[11,51,56,70,74]$. This paradox can be explained by the fact that a study was carried out around a large recycling site, which was highly contaminated by $\mathrm{Cd}[46]$. 
Comparing the upper values of $\mathrm{Cd}$ in water with the WHO guidelines, it can be seen that some concentrations are above the recommended limit (see Figure S7). These limit exceedances have been observed in China [46,51,70,75], Nigeria [11,74] and India [56].

\subsubsection{Chromium in Water}

In this group, eight studies were identified in six countries. Combined, these studies analyzed 235 water samples. The pooled central median concentration of $\mathrm{Cr}$ in water was $0.0022 \mathrm{mg} / \mathrm{L}$ (see Figure 3) (IQR: $0.00023-0.02 \mathrm{mg} / \mathrm{L}$ ), with the upper bound median value being $0.0028 \mathrm{mg} / \mathrm{L}$ (Table 2 and Figure S8). The highest concentrations were recorded in China [46], followed by India [56], Thailand [54], Australia [71] and Ghana [72] (see Figure S8). Analysis of the upper values reported in the literature according to the sampling area shows that water around recycling sites $[46,54,72]$ is more contaminated by $\mathrm{Cr}$, followed by actual recycling sites $[54,56,71]$ (see Table 3 ). This may be explained by the fact that the study by Luo, Liu, Wang, Liu, Li, Zhang and Li [46] was conducted around a large recycling site heavily contaminated by $\mathrm{Cr}$.

The comparison between the upper values reported in the literature and the WHO guidelines shows that several reported $\mathrm{Cr}$ concentrations in water are above the guidelines (see Figure S8). Exceedances have been recorded in China [46], India [56] and Thailand [68].

\subsubsection{Lead in Water}

In this group, 10 studies from six countries were identified. Combined, these studies analyzed 287 water samples. The combined central median concentration of $\mathrm{Pb}$ in water was $0.0063 \mathrm{mg} / \mathrm{L}$ (see Figure 3) (IQR: $0.00027-0.227 \mathrm{mg} / \mathrm{L}$ ). The upper bound median value was $0.01 \mathrm{mg} / \mathrm{L}$ (Table 2 and Figure S9). The highest concentrations were recorded in China [46], followed by Nigeria [74], Thailand [54], India [56], Australia [71] and Ghana [68] (see Figure S9). It should be noted that according to the analysis of the upper values reported in the literature, water from around recycling sites $[46,54,74,75]$ is more contaminated with $\mathrm{Pb}$, followed by recycling sites [11,54,56,70,74] (see Table 3). This contrast can be explained by the high concentrations reported in the study by Luo, $\mathrm{Liu}$, Wang, Liu, Li, Zhang and Li [46] which was conducted in a heavily polluted around recycling site.

As shown in Figure S9, the comparison between WHO guidelines and upper $\mathrm{Pb}$ values in water has shown concentrations above the standard in several countries. These non-standard concentrations have been recorded in China [46,70,75], Nigeria [11,74], Thailand [54], India [56] and Australia [71].

\subsubsection{Mercury in Water}

Regarding water contamination by mercury, four studies from three countries were identified. Combined, these studies analyzed 132 water samples. The pooled central median concentration of $\mathrm{Hg}$ in water was $0.0005 \mathrm{mg} / \mathrm{L}$ (see Figure 3) (IQR: 0.0005-0.00125 mg/L), with the upper bound median value being $0.0005 \mathrm{mg} / \mathrm{L}$ (Table 2 and Figure S10). China [67], followed by India [56] and Ghana [72], recorded the highest concentrations (see Figure S10). Analysis of the upper values of $\mathrm{Hg}$ according to the sampling areas showed that water from recycling sites $[56,70]$ is the most contaminated with $\mathrm{Hg}$ (see Table 3 ).

Upper values of $\mathrm{Hg}$ in water compared with $\mathrm{WHO}$ guidelines show that, in China, there are concentrations above the recommended limit [67]. After synthesizing all the information of all heavy metals in water, it is important to point out that the studies on water contamination included in this review were mostly conducted in Asia, especially in China. Research initiatives should therefore be encouraged in other developing regions of the world, such as South America, Southeast Europe and Africa. Indeed, a large and balanced amount of scientific data will undoubtedly provide a more comprehensive view of the adverse effects of e-waste recycling on ecosystems. In addition, the highest concentrations were all recorded in China and, therefore, in Asia. This situation could lead to public health problems. Indeed, heavy metals are bio-accumulative and heat-resistant 
pollutants [54,76], and as it is known that people continue to use well water in the kitchen and others use it as drinking water $[77,78]$, we wonder about the morbidity associated with e-waste activities. Indeed, several other studies have proven the harmful effects of heavy metals on human health $[27,79,80]$.

\subsection{Sediment Contamination}

The median values of heavy metal concentrations ( $\mathrm{As}, \mathrm{Cd}, \mathrm{Cr}, \mathrm{Pb}$ and $\mathrm{Hg}$ ) in sediment by country are summarized in Figure 4 . In addition, Table 2 summarizes the middle and upper values of each heavy metal, each sample type and sample size. The Supplemental Materials provide details on sample sizes and middle and upper values of each heavy metal.

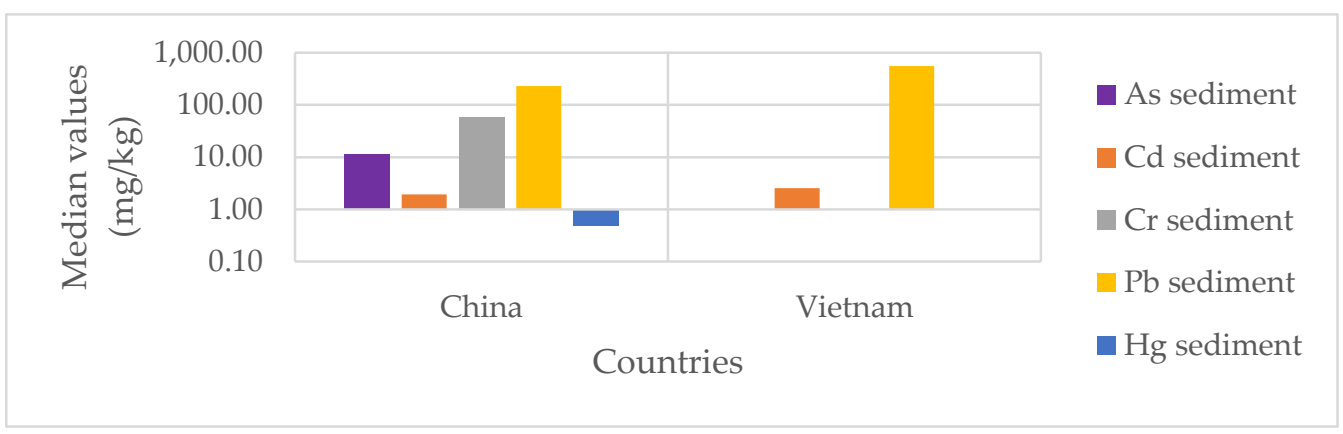

Figure 4. Median concentrations of heavy metals in sediment by country.

\subsubsection{Arsenic in Sediment}

Only three studies-all conducted in China-were found on the contamination of sediment by As. The studies analyzed a total of 107 sediment samples. The median central pooled concentration of As in sediment was $11.3 \mathrm{mg} / \mathrm{kg}$ (see Figure 4) (IQR: 8.02-11.45 mg/kg), with the upper bound median value being $15.55 \mathrm{mg} / \mathrm{kg}$ (Table 2 and Figure S11). The highest concentrations were recorded at recycling sites [70]. Thus, recycling sites are the most contaminated, just ahead of free recycling sites [81] (see Table 3). This shows the extent of the effect that contaminated sites can have on the contamination of areas that are not covered by e-waste recycling activities.

It is important to note that all values reported in the literature on As in sediment $[39,70,81]$ are above the limit recommended by the USEPA guidelines (see Figure S11).

\subsubsection{Cadmium in Sediment}

Twelve studies, conducted in two countries (China and Vietnam), were found on the contamination of sediment by $\mathrm{Cd}$, with 11 of them conducted in China. These studies analyzed 347 sediment samples in all. The combined central median concentration of $\mathrm{Cd}$ in sediment was $2.15 \mathrm{mg} / \mathrm{kg}$ (see Figure 4) (IQR: $1.01-4.8 \mathrm{mg} / \mathrm{kg}$ ), with the upper bound median value being $3.52 \mathrm{mg} / \mathrm{kg}$ (Table 2 and Figure S12). The highest concentrations were recorded in China [81-83], followed by Vietnam [45] (see Figure S12). Analysis of upper $\mathrm{Cd}$ values in sediment, by sampling area, showed that recycling sites $[45,70,81,82,84-86]$ and areas around recycling sites $[39,61,83,87,88]$ are simultaneously the most contaminated (see Table 3).

By comparing the upper values of $\mathrm{Cd}$ in sediment with the USEPA guidelines, all of the studies reported concentrations above the recommended threshold (see Figure S12). It should be noted that even non-recycling sites $[61,81,84]$ have values above the standard, which testifies to the influence of recycling site contamination on areas where e-waste is not recycled.

\subsubsection{Chromium in Sediment}

Only three studies, all conducted in China, showed Cr contamination in sediment. Combined, these studies analyzed 171 sediment samples. The combined central median 
concentration of $\mathrm{Cr}$ in the sediment was $58 \mathrm{mg} / \mathrm{kg}$ (see Figure 4) (IQR: 39.52-67.72 mg/kg), with the upper bound median value being $129.5 \mathrm{mg} / \mathrm{kg}$ (Table 2 and Figure S13). Analysis of upper Cr values in sediment, by sampling area, showed that recycling sites $[81,82,84,85]$ are the most polluted, followed by areas around recycling sites $[61,83,87]$ (see Table 3).

As presented in Figure S13, the comparison between the upper values of $\mathrm{Cr}$ in sediment and the USEPA guidelines shows that all the studies reported concentrations above the recommended limit. It should be noted that even studies including non-recycling sites $[61,81,83,84]$ have reported $\mathrm{Cr}$ concentrations above the limit allowed in sediment, indicating the influence of recycling site contamination on areas where e-waste is not recycled.

\subsubsection{Lead in Sediment}

Thirteen studies, conducted in two countries (China and Vietnam), were found on the contamination of sediment by $\mathrm{Pb}$, of which 12 were conducted in China. Combined, these studies analyzed 371 sediment samples. The pooled central median concentration of lead in sediment was $233.5 \mathrm{mg} / \mathrm{kg}$ (see Figure 4) (IQR: 65.1-528.87 mg/kg), with the upper bound median value being $287 \mathrm{mg} / \mathrm{kg}$ (Table 2 and Figure S14). The highest concentrations were recorded in China [89] and then Vietnam [45]. Analysis of upper Pb values in sediment by sampling area showed that recycling sites $[45,70,81-86,89]$ are the most polluted, followed by areas around recycling sites $[39,61,83,87,89]$ (see Table 3 ).

By comparing the upper values of $\mathrm{Pb}$ in sediment with the USEPA guidelines, all the studies reported concentrations above the recommended limit (see Figure S14). It should be noted that even non-recycling sites $[61,83,84]$ had values above the standard, which testifies to the influence of recycling site contamination on areas where e-waste is not recycled.

\subsubsection{Mercury in Sediment}

Only three studies, all conducted in China, reported on $\mathrm{Hg}$ contamination in sediments. Combined, these studies analyzed 107 sediment samples. The median central pooled concentration of $\mathrm{Hg}$ in the sediment was $0.49 \mathrm{mg} / \mathrm{kg}$ (see Figure 4) (IQR: 0.12-0.84 mg/kg), with the upper bound median value being $0.95 \mathrm{mg} / \mathrm{kg}$ (Table 2 and Figure S15). The highest concentrations were recorded at recycling sites [70,81]. As presented in Figure S15, the comparison between the upper values of $\mathrm{Hg}$ in sediment and the USEPA guidelines shows that the studies by Guo, Huang, Zhang and Dong [70] and Chen, Yu, Shen, Zhang, Liu, Shen, Tang and Chen [81] reported concentrations above the recommended limit. It should be noted that even the study by Chen, Yu, Shen, Zhang, Liu, Shen, Tang and Chen [81], which included free recycling sites, found $\mathrm{Hg}$ concentrations above the limit allowed in sediments, indicating the influence of recycling site contamination on areas where e-waste is not recycled.

In synthesizing information on heavy metal pollution in sediments, we noticed that almost all these studies were conducted in China. There is therefore a need for research in other parts of the world for a global analysis of the situation.

\section{Conclusions}

This systematic review analyzed peer-reviewed studies published between the years 2005 and 2017 that reported on $\mathrm{As}, \mathrm{Cd}, \mathrm{Cr}, \mathrm{Hg}$ and Pb levels in soil, water and sediment collected from areas that recycle e-waste. In general, there are five broad conclusions of this work. First, across all studies, the concentrations of metals in a given medium are generally higher than international standards. Second, the risks associated with such exposures for both human health and the environment are not well characterized, and, as such, further studies are needed. Third, there are geographical data gaps, as most studies were from Asia (notably China). As e-waste recycling occurs in many countries worldwide, there is a need to increase research in other geographical areas like Africa, Oceania, Europe, America and even in Asian countries other than China. This will allow a clearer comparison between contamination within developing countries (often conducted in the informal sector without regulations) and that of developed countries (with a regulatory framework establishing 
clear guidelines for recycling, and health and safety rules). Here, we only focused on papers published in English and French, and we acknowledge that studies published in different languages were missing. Fourth, we note that many studies did not include key variables (e.g., exact sampling dates, reference materials, analytical quality control, control sites). A future study of this kind could design a risk of bias score to identify (and better consider) higher quality studies. Fifth, the findings here raise concern about metal contamination at e-waste sites worldwide, and thus it is imperative for actions (e.g., policy changes, engineering solutions, educational campaigns) to be taken at these sites to help reduce exposure (and thus risk).

Supplementary Materials: The supplemental data are available at https:/ /www.mdpi.com/article/ 10.3390/ijerph18073517/s1. Figure S1: Middle and upper values of soil As concentrations; Figure S2: Middle and upper values of soil Cd concentrations; Figure S3: Middle and upper values of soil $\mathrm{Cr}$ concentrations; Figure S4: Middle and upper values of soil $\mathrm{Pb}$ concentrations; Figure S5: Middle and upper values of soil $\mathrm{Hg}$ concentrations; Figure S6: Middle and upper values of water As concentrations; Figure S7: Middle and upper values of water Cd concentrations; Figure S8: Middle and upper values of water $\mathrm{Cr}$ concentrations; Figure S9: Middle and upper values of water $\mathrm{Pb}$ concentrations; Figure S10: Middle and upper values of water Hg concentrations; Figure S11: Middle and upper values of sediment As concentrations; Figure S12: Middle and upper values of sediment $\mathrm{Cd}$ concentrations; Figure S13: Middle and upper values of sediment $\mathrm{Cr}$ concentrations; Figure S14: Middle and upper values of sediments Pb concentrations; Figure S15: Middle and upper values of sediment $\mathrm{Hg}$ concentrations.

Author Contributions: Conceptualization: M.G.K.H. and N.B.; methodology: N.B., M.G.K.H. and J.N.F.; software: M.G.K.H.; validation: N.B., N.M.K., J.N.F., C.B., E.-M.D.O. and B.F.; formal analysis: M.G.K.H. and S.A.T.; investigation: M.G.K.H., S.A.T. and N.B.; data curation: M.G.K.H. and N.B.; writing—original draft preparation: M.G.K.H.; writing—review and editing: N.B., J.N.F., C.B., E.M.D.O. and B.F.; visualization: N.B., N.M.K., J.N.F., C.B., E.-M.D.O. and B.F.; supervision: N.B., C.B., E.-M.D.O.; project administration: N.B. and J.N.F; funding acquisition: N.B. and J.N.F. All authors have read and agreed to the published version of the manuscript.

Funding: Financial support was obtained from Canada's International Development Research Centre and the U.S. National Institutes of Health's Global Environmental and Occupational Health (GEOHealth) program (funding number U01TW010103) to achieve this work.

Institutional Review Board Statement: Not applicable.

Informed Consent Statement: Not applicable.

Data Availability Statement: Data from the literature search in this review are available from the corresponding authors (karelhouessionon@yahoo.fr).

Acknowledgments: We thank the anonymous peer reviewers for their constructive insights. We thank also members of the Basu lab team at McGill University for their technical support. All our gratitude to Angelo Satoguina and Gloria Ayivi-Vinz for reviewing the final document.

Conflicts of Interest: The authors declare no conflict of interest. The sponsors had no role in the design, execution, interpretation, or writing of the study.

\author{
Abbreviations \\ E-waste Electronic waste \\ IQR Interquartile range \\ U.S. NIEHS United States National Institute of Environmental Health Sciences \\ USEPA United States Environmental Protection Agency \\ WHO World Health Organization
}

\title{
References
}

1. Heacock, M.; Kelly, C.B.; Suk, W.A. E-waste: The growing global problem and next steps. Rev. Environ. Health 2016, 31, 131-135. [CrossRef] [PubMed] 
2. $\quad$ Landrigan, P.J.; Fuller, R.; Acosta, N.J.R.; Adeyi, O.; Arnold, R.; Basu, N.N.; Balde, A.B.; Bertollini, R.; Bose-O’Reilly, S.; Boufford, J.I.; et al. The Lancet Commission on pollution and health. Lancet 2018, 391, 462-512. [CrossRef]

3. Balde, C.P.; Forti, V.; Gray, V.; Kuehr, R.; Stegmann, P. The Global E-Waste Monitor 2017: Quantities, Flows and Resources; United Nations University: Bonn, Geramny; International Telecommunication Union: Geneva, Switzerland; International Solid Waste Association: Vienna, Austria, 2017.

4. Breivik, K.; Armitage, J.M.; Wania, F.; Jones, K.C. Tracking the global generation and exports of e-waste. Do existing estimates add up? Environ. Sci. Technol. 2014, 48, 8735-8743. [CrossRef] [PubMed]

5. Lundgren, K. The Global Impact of E-Waste: Addressing the Challenge; International Labour Organization: Geneva, Switzerland, 2012.

6. Sthiannopkao, S.; Wong, M.H. Handling e-waste in developed and developing countries: Initiatives, practices, and consequences. Sci. Total Environ. 2013, 463, 1147-1153. [CrossRef]

7. Shirodkar, N.; Terkar, R. Stepped Recycling: The Solution for E-waste Management and Sustainable Manufacturing in India. Mater. Today-Proc. 2017, 4, 8911-8917. [CrossRef]

8. Lin, S.; Man, Y.B.; Chow, K.L.; Zheng, C.; Wong, M.H. Impacts of the influx of e-waste into Hong Kong after China has tightened up entry regulations. Crit. Rev. Environ. Sci. Technol. 2020, 50, 105-134. [CrossRef]

9. Rucevska, I.; Nellemann, C.; Isarin, N.; Yang, W.; Liu, N.; Yu, K.; Sandnaes, S.; Olley, K.; McCann, H.; Devia, L. Waste CrimeWaste Risks: Gaps in Meeting the Global Waste Challenge. A UNEP Rapid Response Assessment. 2017. Available online: https:/ / wedocs.unep.org/handle/20.500.11822/9648 (accessed on 26 March 2021).

10. Akortia, E.; Olukunle, O.I.; Daso, A.P.; Okonkwo, J.O. Soil concentrations of polybrominated diphenyl ethers and trace metals from an electronic waste dump site in the Greater Accra Region, Ghana: Implications for human exposure. Ecotoxicol. Environ. Saf. 2017, 137, 247-255. [CrossRef]

11. Alabi, A.O.; Bakare, A.A. Genetic damage induced by electronic waste leachates and contaminated underground water in two prokaryotic systems. Toxicol. Mech. Methods 2017, 27, 657-665. [CrossRef]

12. Awasthi, A.K.; Zeng, X.; Li, J. Environmental pollution of electronic waste recycling in India: A critical review. Environ. Pollut. 2016, 211, 259-270. [CrossRef]

13. Chakraborty, P.; Selvaraj, S.; Nakamura, M.; Prithiviraj, B.; Ko, S.; Loganathans, B. E-Waste and Associated Environmental Contamination in the Asia/Pacific Region (Part 2): A Case Study of Dioxins and Furans in E-Waste Recycling/Dump Sites in India. In Persistent Organic Chemicals in the Environment: Status and Trends in the Pacific Basin Countries I: Contamination Status; Loganathan, B.G., Khim, J.S., Kodavanti, P.R.S., Masunaga, S., Eds.; Amer Chemical Soc: Washington, DC, USA, 2016; Volume 1243, pp. 139-154.

14. Chin-Pampillo, J.S.; Masis-Mora, M.; Ruiz-Hidalgo, K.; Carazo-Rojas, E.; Rodriguez-Rodriguez, C.E. Removal of carbofuran is not affected by co-application of chlorpyrifos in a coconut fiber/compost based biomixture after aging or pre-exposure. J. Environ. Sci. 2016, 46, 182-189. [CrossRef]

15. Neto, G.C.D.; Correia, A.D.C.; Schroeder, A.M. Economic and environmental assessment of recycling and reuse of electronic waste: Multiple case studies in Brazil and Switzerland. Resour. Conserv. Recycl. 2017, 127, 42-55. [CrossRef]

16. Huang, J.; Nkrumah, P.N.; Anim, D.O.; Mensah, E. E-waste disposal effects on the aquatic environment: Accra, Ghana. Rev. Environ. Contam. Toxicol. 2014, 229, 19-34. [CrossRef] [PubMed]

17. Ackah, M. Informal E-waste recycling in developing countries: Review of metal(loid)s pollution, environmental impacts and transport pathways. Environ. Sci. Pollut. Res. 2017, 24, 24092-24101. [CrossRef]

18. Damrongsiri, S.; Vassanadumrongdee, S.; Tanwattana, P. Heavy metal contamination characteristic of soil in WEEE (waste electrical and electronic equipment) dismantling community: A case study of Bangkok, Thailand. Environ. Sci. Pollut. Res. Int. 2016, 23, 17026-17034. [CrossRef] [PubMed]

19. dos Santos, F.R.; de Almeida, E.; Kemerich, P.D.D.; Melquiades, F.L. Evaluation of metal release from battery and electronic components in soil using SR-TXRF and EDXRF. X-Ray Spectrom. 2017, 46, 512-521. [CrossRef]

20. Fayiga, A.O.; Ipinmoroti, M.O.; Chirenje, T. Environmental pollution in Africa. Environ. Dev. Sustain. 2018, 20, 41-73. [CrossRef]

21. Flegal, A.R.; Gallon, C.; Ganguli, P.M.; Conaway, C.H. All the Lead in China. Crit. Rev. Environ. Sci. Technol. 2013, 43, 1869-1944. [CrossRef]

22. Fu, J.; Zhou, Q.; Liu, J.; Liu, W.; Wang, T.; Zhang, Q.; Jiang, G. High levels of heavy metals in rice (Oryza sativa L.) from a typical E-waste recycling area in southeast China and its potential risk to human health. Chemosphere 2008, 71, 1269-1275. [CrossRef]

23. Fujimori, T.; Takigami, H. Pollution distribution of heavy metals in surface soil at an informal electronic-waste recycling site. Environ. Geochem. Health 2014, 36, 159-168. [CrossRef]

24. Gao, B.; Zhou, H.; Liang, X.; Tu, X. Cd isotopes as a potential source tracer of metal pollution in river sediments. Environ. Pollut. 2013, 181, 340-343. [CrossRef]

25. Gu, W.; Bai, J.; Yao, H.; Zhao, J.; Zhuang, X.; Huang, Q.; Zhang, C.; Wang, J. Heavy metals in soil at a waste electrical and electronic equipment processing area in China. Waste Manag. Res. 2017, 35, 1183-1191. [CrossRef] [PubMed]

26. Hahladakis, J.N.; Stylianos, M.; Gidarakos, E. Assessment of released heavy metals from electrical and electronic equipment (EEE) existing in shipwrecks through laboratory-scale simulation reactor. J. Hazard. Mater. 2013, 250-251, 256-264. [CrossRef]

27. Han, Z.X.; Wang, N.; Zhang, H.L.; Yang, X.Y. Heavy metal contamination and risk assessment of human exposure near an e-waste processing site. Acta Agric. Scand. Sect. B-Soil Plant Sci. 2017, 67, 119-125. [CrossRef] 
28. Agyei-Mensah, S.; Oteng-Ababio, M. Perceptions of health and environmental impacts of e-waste management in Ghana. Int. J. Environ. Health Res. 2012, 22, 500-517. [CrossRef] [PubMed]

29. Heacock, M.; Trottier, B.; Adhikary, S.; Asante, K.A.; Basu, N.; Brune, M.N.; Caravanos, J.; Carpenter, D.; Cazabon, D.; Chakraborty, P.; et al. Prevention-intervention strategies to reduce exposure to e-waste. Rev. Environ. Health 2018, 33, 219-228. [CrossRef]

30. Song, Q.B.; Li, J.H. Environmental effects of heavy metals derived from the e-waste recycling activities in China: A systematic review. Waste Manag. 2014, 34, 2587-2594. [CrossRef]

31. Sun, L.Y.; Zeng, X.L.; Li, J.H. Pollutants release and control during WEEE recycling: A critical review. In Selected Proceedings of the Tenth International Conference on Waste Management and Technology; Li, J., Dong, F., Eds.; Elsevier Science Bv: Amsterdam, The Netherlands, 2016; Volume 31, pp. 867-872.

32. Wong, M.H.; Wu, S.C.; Deng, W.J.; Yu, X.Z.; Luo, Q.; Leung, A.O.W.; Wong, C.S.C.; Luksemburg, W.J.; Wong, A.S. Export of toxic chemicals-A review of the case of uncontrolled electronic-waste recycling. Environ. Pollut. 2007, 149, 131-140. [CrossRef]

33. Rooney, A.A.; Boyles, A.L.; Wolfe, M.S.; Bucher, J.R.; Thayer, K.A. Systematic review and evidence integration for literature-based environmental health science assessments. Environ. Health Perspect. 2014, 122, 711. [CrossRef]

34. Zhang, Q.; Ye, J.J.; Chen, J.Y.; Xu, H.J.; Wang, C.; Zhao, M.R. Risk assessment of polychlorinated biphenyls and heavy metals in soils of an abandoned e-waste site in China. Environ. Pollut. 2014, 185, 258-265. [CrossRef]

35. Li, J.H.; Duan, H.B.; Shi, P.X. Heavy metal contamination of surface soil in electronic waste dismantling area: Site investigation and source-apportionment analysis. Waste Manag. Res. 2011, 29, 727-738. [CrossRef]

36. Wu, W.C.; Dong, C.X.; Wu, J.H.; Liu, X.W.; Wu, Y.X.; Chen, X.B.; Yu, S.X. Ecological effects of soil properties and metal concentrations on the composition and diversity of microbial communities associated with land use patterns in an electronic waste recycling region. Sci. Total Environ. 2017, 601, 57-65. [CrossRef] [PubMed]

37. He, K.L.; Sun, Z.H.; Hu, Y.A.; Zeng, X.Y.; Yu, Z.Q.; Cheng, H.F. Comparison of soil heavy metal pollution caused by e-waste recycling activities and traditional industrial operations. Environ. Sci. Pollut. Res. 2017, 24, 9387-9398. [CrossRef] [PubMed]

38. USEPA. Regional Screening Levels (RSLs)—Generic Tables; United States Environmental Protection Agency: Washington, DC, USA, 2017.

39. Wang, J.X.; Liu, L.L.; Wang, J.F.; Pan, B.S.; Fu, X.X.; Zhang, G.; Zhang, L.; Lin, K.F. Distribution of metals and brominated flame retardants (BFRs) in sediments, soils and plants from an informal e-waste dismantling site, South China. Environ. Sci. Pollut. Res. 2015, 22, 1020-1033. [CrossRef] [PubMed]

40. Tokumaru, T.; Ozaki, H.; Onwona-Agyeman, S.; Ofosu-Anim, J.; Watanabe, I. Determination of the Extent of Trace Metals Pollution in Soils, Sediments and Human Hair at e-Waste Recycling Site in Ghana. Arch. Environ. Contam. Toxicol. 2017, 73, 377-390. [CrossRef]

41. Yang, Y.C.; Xue, M.Q.; Xu, Z.M.; Huang, C. Health risk assessment of heavy metals (Cr, Ni, Cu, Zn, Cd, Pb) in circumjacent soil of a factory for recycling waste electrical and electronic equipment. J. Mater. Cycles Waste Manag. 2013, 15, 556-563. [CrossRef]

42. Ha, N.N.; Agusa, T.; Ramu, K.; Tu, N.P.C.; Murata, S.; Bulbule, K.A.; Parthasaraty, P.; Takahashi, S.; Subramanian, A.; Tanabe, S. Contamination by trace elements at e-waste recycling sites in Bangalore, India. Chemosphere 2009, 76, 9-15. [CrossRef]

43. Isimekhai, K.A.; Garelick, H.; Watt, J.; Purchase, D. Heavy metals distribution and risk assessment in soil from an informal E-waste recycling site in Lagos State, Nigeria. Environ. Sci. Pollut. Res. Int. 2017, 24, 17206-17219. [CrossRef]

44. Lopez, B.N.; Man, Y.B.; Zhao, Y.G.; Zheng, J.S.; Leung, A.O.W.; Yao, J.; Wong, M.H. Major Pollutants in Soils of Abandoned Agricultural Land Contaminated by e-Waste Activities in Hong Kong. Arch. Environ. Contam. Toxicol. 2011, 61, 101-114. [CrossRef]

45. Oguri, T.; Suzuki, G.; Matsukami, H.; Uchida, N.; Tue, N.M.; Tuyen, L.H.; Viet, P.H.; Takahashi, S.; Tanabe, S.; Takigami, H. Exposure assessment of heavy metals in an e-waste processing area in northern Vietnam. Sci. Total Environ. 2018, 621, 1115-1123. [CrossRef]

46. Luo, C.L.; Liu, C.P.; Wang, Y.; Liu, X.A.; Li, F.B.; Zhang, G.; Li, X.D. Heavy metal contamination in soils and vegetables near an e-waste processing site, south China. J. Hazard. Mater. 2011, 186, 481-490. [CrossRef]

47. Zhang, J.H.; Fan, W.W. Metal partitioning and relationships to soil microbial properties of submerged paddy soil contaminated by electronic waste recycling. Chem. Ecol. 2015, 31, 147-159. [CrossRef]

48. Alabi, O.A.; Bakare, A.A.; Xu, X.; Li, B.; Zhang, Y.; Huo, X. Comparative evaluation of environmental contamination and DNA damage induced by electronic-waste in Nigeria and China. Sci. Total Environ. 2012, 423, 62-72. [CrossRef] [PubMed]

49. Liu, M.; Huang, B.; Bi, X.H.; Ren, Z.F.; Sheng, G.Y.; Fu, J.M. Heavy metals and organic compounds contamination in soil from an e-waste region in South China. Environ. Sci.-Process. Impacts 2013, 15, 919-929. [CrossRef] [PubMed]

50. Wu, C.F.; Luo, Y.M.; Deng, S.P.; Teng, Y.; Song, J. Spatial characteristics of cadmium in topsoils in a typical e-waste recycling area in southeast China and its potential threat to shallow groundwater. Sci. Total Environ. 2014, 472, 556-561. [CrossRef]

51. Itai, T.; Otsuka, M.; Asante, K.A.; Muto, M.; Opoku-Ankomah, Y.; Ansa-Asare, O.D.; Tanabe, S. Variation and distribution of metals and metalloids in soil/ash mixtures from Agbogbloshie e-waste recycling site in Accra, Ghana. Sci. Total Environ. 2014, 470-471, 707-716. [CrossRef]

52. Kyere, V.N.; Greve, K.; Atiemo, S.M. Spatial assessment of soil contamination by heavy metals from informal electronic waste recycling in Agbogbloshie, Ghana. Environ. Health Toxicol. 2016, 31, e2016006. [CrossRef]

53. Neeratanaphan, L.; Khamma, S.; Benchawattananon, R.; Ruchuwararak, P.; Appamaraka, S.; Intamat, S. Heavy metal accumulation in rice (Oryza sativa) near electronic waste dumps and related human health risk assessment. Hum. Ecol. Risk Assess. 2017, 23, 1086-1098. [CrossRef] 
54. Han, W.; Gao, G.; Geng, J.; Li, Y.; Wang, Y. Ecological and health risks assessment and spatial distribution of residual heavy metals in the soil of an e-waste circular economy park in Tianjin, China. Chemosphere 2018, 197, 325-335. [CrossRef]

55. Pradhan, J.K.; Kumar, S. Informal e-waste recycling: Environmental risk assessment of heavy metal contamination in Mandoli industrial area, Delhi, India. Environ. Sci. Pollut. Res. Int. 2014, 21, 7913-7928. [CrossRef]

56. Zhao, W.T.; Ding, L.; Gu, X.W.; Luo, J.; Liu, Y.L.; Guo, L.; Shi, Y.; Huang, T.; Cheng, S.G. Levels and ecological risk assessment of metals in soils from a typical e-waste recycling region in southeast China. Ecotoxicology 2015, 24, 1947-1960. [CrossRef]

57. Wu, Q.H.; Leung, J.Y.S.; Geng, X.H.; Chen, S.J.; Huang, X.X.; Li, H.Y.; Huang, Z.Y.; Zhu, L.B.; Chen, J.H.; Lu, Y.Y. Heavy metal contamination of soil and water in the vicinity of an abandoned e-waste recycling site: Implications for dissemination of heavy metals. Sci. Total Environ. 2015, 506, 217-225. [CrossRef]

58. Jun-hui, Z.; Hang, M. Eco-toxicity and metal contamination of paddy soil in an e-wastes recycling area. J. Hazard. Mater. 2009, 165, 744-750. [CrossRef]

59. Quan, S.X.; Yan, B.; Yang, F.; Li, N.; Xiao, X.M.; Fu, J.M. Spatial distribution of heavy metal contamination in soils near a primitive e-waste recycling site. Environ. Sci. Pollut. Res. Int. 2015, 22, 1290-1298. [CrossRef]

60. Tang, X.; Shen, C.; Shi, D.; Cheema, S.A.; Khan, M.I.; Zhang, C.; Chen, Y. Heavy metal and persistent organic compound contamination in soil from Wenling: An emerging e-waste recycling city in Taizhou area, China. J. Hazard. Mater. 2010, 173, 653-660. [CrossRef]

61. Yekeen, T.A.; Xu, X.J.; Zhang, Y.L.; Wu, Y.S.; Kim, S.; Reponen, T.; Dietrich, K.N.; Ho, S.M.; Chen, A.M.; Huo, X. Assessment of health risk of trace metal pollution in surface soil and road dust from e-waste recycling area in China. Environ. Sci. Pollut. Res. 2016, 23, 17511-17524. [CrossRef]

62. Pascale, A.; Sosa, A.; Bares, C.; Battocletti, A.; Moll, M.J.; Pose, D.; Laborde, A.; Gonzalez, H.; Feola, G. E-Waste Informal Recycling: An Emerging Source of Lead Exposure in South America. Ann. Glob. Health 2016, 82, 197-201. [CrossRef] [PubMed]

63. Jiang, L.F.; Cheng, Z.N.; Zhang, D.Y.; Song, M.K.; Wang, Y.J.; Luo, C.L.; Yin, H.; Li, J.; Zhang, G. The influence of e-waste recycling on the molecular ecological network of soil microbial communities in Pakistan and China. Environ. Pollut. 2017, 231, 173-181. [CrossRef] [PubMed]

64. Chen, F.; Yang, B.D.; Ma, J.; Qu, J.F.; Liu, G.J. Decontamination of electronic waste-polluted soil by ultrasound-assisted soil washing. Environ. Sci. Pollut. Res. 2016, 23, 20331-20340. [CrossRef] [PubMed]

65. Cui, J.L.; Luo, C.L.; Tang, C.W.Y.; Chan, T.S.; Li, X.D. Speciation and leaching of trace metal contaminants from e-waste contaminated soils. J. Hazard. Mater. 2017, 329, 150-158. [CrossRef] [PubMed]

66. Wei, L.; Wang, S.T.; Zuo, Q.Q.; Liang, S.X.; Shen, S.G.; Zhao, C.X. Nano-hydroxyapatite alleviates the detrimental effects of heavy metals on plant growth and soil microbes in e-waste-contaminated soil. Environ. Sci.-Process. Impacts 2016, 18, 760-767. [CrossRef]

67. Tang, W.; Cheng, J.P.; Zhao, W.C.; Wang, W.H. Mercury levels and estimated total daily intakes for children and adults from an electronic waste recycling area in Taizhou, China: Key role of rice and fish consumption. J. Environ. Sci. 2015, 34, 107-115. [CrossRef]

68. Zhang, W.H.; Wu, Y.X.; Simonnot, M.O. Soil Contamination due to E-Waste Disposal and Recycling Activities: A Review with Special Focus on China. Pedosphere 2012, 22, 434-455. [CrossRef]

69. Britt, S.L.; Parker, B.L.; Cherry, J.A. A downhole passive sampling system to avoid bias and error from groundwater sample handling. Environ. Sci. Technol. 2010, 44, 4917-4923. [CrossRef] [PubMed]

70. Guo, Y.; Huang, C.J.; Zhang, H.; Dong, Q.X. Heavy Metal Contamination from Electronic Waste Recycling at Guiyu, Southeastern China. J. Environ. Qual. 2009, 38, 1617-1626. [CrossRef]

71. Kiddee, P.; Naidu, R.; Wong, M.H.; Hearn, L.; Muller, J.F. Field investigation of the quality of fresh and aged leachates from selected landfills receiving e-waste in an arid climate. Waste Manag. 2014, 34, 2292-2304. [CrossRef]

72. Asante, K.A.; Agusa, T.; Biney, C.A.; Agyekum, W.A.; Bello, M.; Otsuka, M.; Itai, T.; Takahashi, S.; Tanabe, S. Multi-trace element levels and arsenic speciation in urine of e-waste recycling workers from Agbogbloshie, Accra in Ghana. Sci. Total Environ. 2012, 424, 63-73. [CrossRef]

73. WHO. Guidelines for Drinking-Water Quality; World Health Organization: Geneva, Switzerland, 2011; Volume 216, pp. 303-304.

74. Alabi, O.A.; Bakare, A.A. Cytogenotoxic Effects and Reproductive Abnormalities Induced by e-Waste Contaminated Underground Water in Mice. Cytologia 2014, 79, 331-340. [CrossRef]

75. Zheng, J.; Chen, K.H.; Yan, X.; Chen, S.J.; Hu, G.C.; Peng, X.W.; Yuan, J.G.; Mai, B.X.; Yang, Z.Y. Heavy metals in food, house dust, and water from an e-waste recycling area in South China and the potential risk to human health. Ecotoxicol. Environ. Saf. 2013, 96, 205-212. [CrossRef] [PubMed]

76. Cesniene, T.; Kleizaite, V.; Bondzinskaite, S.; Taraskevicius, R.; Zvingila, D.; Siuksta, R.; Rancelis, V. Metal bioaccumulation and mutagenesis in a Tradescantia clone following long-term exposure to soils from urban industrial areas and closed landfills. Mutat. Res. 2017, 823, 65-72. [CrossRef] [PubMed]

77. DiGiulio, D.C.; Jackson, R.B. Impact to Underground Sources of Drinking Water and Domestic Wells from Production Well Stimulation and Completion Practices in the Pavillion, Wyoming, Field. Environ. Sci. Technol. 2016, 50, 4524-4536. [CrossRef]

78. Pfaff, A.; Schoenfeld, A.; Ahmed, K.M.; van Geen, A. Reduction in exposure to arsenic from drinking well-water in Bangladesh limited by insufficient testing and awareness. J. Water Sanit. Hyg. Dev. A J. Int. Water Assoc. 2017, 7, 331-339. [CrossRef] 
79. Cao, S.; Duan, X.; Zhao, X.; Wang, B.; Ma, J.; Fan, D.; Sun, C.; He, B.; Wei, F.; Jiang, G. Health risk assessment of various metal(loid)s via multiple exposure pathways on children living near a typical lead-acid battery plant, China. Environ. Pollut. 2015, 200, 16-23. [CrossRef] [PubMed]

80. Henriquez-Hernandez, L.A.; Boada, L.D.; Carranza, C.; Perez-Arellano, J.L.; Gonzalez-Antuna, A.; Camacho, M.; AlmeidaGonzalez, M.; Zumbado, M.; Luzardo, O.P. Blood levels of toxic metals and rare earth elements commonly found in e-waste may exert subtle effects on hemoglobin concentration in sub-Saharan immigrants. Environ. Int. 2017, 109, 20-28. [CrossRef] [PubMed]

81. Chen, L.; Yu, C.N.; Shen, C.F.; Zhang, C.K.; Liu, L.; Shen, K.L.; Tang, X.J.; Chen, Y.X. Study on adverse impact of e-waste disassembly on surface sediment in East China by chemical analysis and bioassays. J. Soils Sediments 2010, 10, 359-367. [CrossRef]

82. Nie, X.P.; Fan, C.P.; Wang, Z.H.; Su, T.; Liu, X.Y.; An, T.C. Toxic assessment of the leachates of paddy soils and river sediments from e-waste dismantling sites to microalga, Pseudokirchneriella subcapitata. Ecotoxicol. Environ. Saf. 2015, 111, 168-176. [CrossRef]

83. Xu, F.; Liu, Y.C.; Wang, J.X.; Zhang, G.; Zhang, W.; Liu, L.L.; Wang, J.F.; Pan, B.S.; Lin, K.F. Characterization of heavy metals and brominated flame retardants in the indoor and outdoor dust of e-waste workshops: Implication for on-site human exposure. Environ. Sci. Pollut. Res. 2015, 22, 5469-5480. [CrossRef] [PubMed]

84. Zhu, Z.M.; Han, Z.X.; Bi, X.Y.; Yang, W.L. The relationship between magnetic parameters and heavy metal contents of indoor dust in e-waste recycling impacted area, Southeast China. Sci. Total Environ. 2012, 433, 302-308. [CrossRef]

85. Quan, S.X.; Yan, B.; Lei, C.; Yang, F.; Li, N.; Xiao, X.M.; Fu, J.M. Distribution of heavy metal pollution in sediments from an acid leaching site of e-waste. Sci. Total Environ. 2014, 499, 349-355. [CrossRef]

86. Liu, J.; Chen, X.; Shu, H.Y.; Lin, X.R.; Zhou, Q.X.; Bramryd, T.; Shu, W.S.; Huang, L.N. Microbial community structure and function in sediments from e-waste contaminated rivers at Guiyu area of China. Environ. Pollut. 2017, 235, 171-179. [CrossRef]

87. Wang, F.; Leung, A.O.W.; Wu, S.C.; Yang, M.S.; Wong, M.H. Chemical and ecotoxicological analyses of sediments and elutriates of contaminated rivers due to e-waste recycling activities using a diverse battery of bioassays. Environ. Pollut. 2009, 157, 2082-2090. [CrossRef]

88. Wong, C.S.C.; Wu, S.C.; Duzgoren-Aydin, N.S.; Aydin, A.; Wong, M.H. Trace metal contamination of sediments in an e-waste processing village in China. Environ. Pollut. 2007, 145, 434-442. [CrossRef] [PubMed]

89. Leung, A.O.W.; Duzgoren-Aydin, N.S.; Cheung, K.C.; Wong, M.H. Heavy metals concentrations of surface dust from e-waste recycling and its human health implications in southeast China. Environ. Sci. Technol. 2008, 42, 2674-2680. [CrossRef] [PubMed] 